\title{
Assessment of the flowability of spray-dried milk powders for chocolate manufacture
}

\author{
John FITZPATRICK ${ }^{\mathrm{a} *}$, Kevin BARRY $^{\mathrm{a}}$, Colin DELANEY ${ }^{\mathrm{a}}$, Kieran $\mathrm{KEOGH}^{\mathrm{b}}$ \\ ${ }^{a}$ Department of Process and Chemical Engineering, University College, Cork, Ireland \\ b Teagasc, Dairy Products Research Centre, Moorepark, Fermoy, Co. Cork, Ireland
}

Published online 14 June 2005

\begin{abstract}
This work reports on the flowability of novel milk powders that have potential for application in the manufacture of chocolate. Many milk powders are cohesive which can give rise to powder flow problems. Shear cell techniques were used to measure the following powder flow properties: powder flowfunction, effective angle of internal friction and angle of wall friction. These measurements were used in assessing cohesion developed within the powders under compaction and adhesion to a stainless steel surface. The work investigated how fat content, free-fat content, particle size, moisture content, lactose content, amorphous lactose content and storage conditions influenced the flowability of the milk powders. Increased fat content reduced powder flowability especially when comparing $1 \%$ and $26 \%$ fat powders. Varying free-fat content showed no effect on flowability. Particle size had a major influence on flowability, as increasing the particle size significantly improved the flowability of powders with $1 \%$ and $26 \%$ fat content. The concentration of amorphous lactose present increased the susceptibility of powders for sorbing moisture, resulting in reduced flowability and caking. Finally, powder flow property measurements can be applied in the design of hoppers and silos that give consistent reliable flow, which is essential in powder handling and processing operations.
\end{abstract}

milk powder / flowability / shear testing / chocolate manufacture

Résumé - Évaluation de l'aptitude à l'écoulement de poudres de lait séché par atomisation utilisables en chocolaterie. Cet article présente les propriétés d'écoulement de nouvelles poudres de lait utilisables dans la fabrication de chocolat. De nombreuses poudres de lait sont collantes, ce qui peut conduire à des problèmes d'écoulement. Des techniques de cisaillement ont été utilisées pour mesurer sur ces poudres les propriétés d'écoulement suivantes : fonction d'écoulement, angle effectif de friction interne et angle de friction à la paroi. Ces mesures ont été utilisées pour évaluer la cohésion à l'intérieur de poudres agglomérées et leur adhésion à une surface en acier inoxydable. Ce travail a montré comment les teneurs en matière grasse et en matière grasse libre, la taille des particules, l'humidité, les teneurs en lactose et en lactose amorphe et les conditions de stockage influencent la coulabilité des poudres de lait. L'augmentation de la teneur en matière grasse conduisait à une diminution de la coulabilité, en particulier en comparant des poudres à $1 \%$ et à $26 \%$ de matière grasse. La variation de la teneur en matière grasse libre n'avait pas d'effet sur la coulabilité. Par contre, la taille des particules avait un effet majeur puisque l'accroissement de la taille des particules améliorait de façon significative la coulabilité des poudres contenant $1 \%$ ou $26 \%$ de matière grasse. La concentration en lactose amorphe présent augmentait la susceptibilité des poudres à la sorption d'eau, entraînant une coulabilité réduite et un mottage. Finalement, les mesures des propriétés d'écoulement des poudres peuvent être appliquées dans la conception de trémies et de silos permettant d'obtenir un écoulement fiable et constant, ce qui est essentiel dans les opérations de manutention et de transformation des poudres.

poudre de lait / écoulement / cisaillement / chocolat

* Corresponding author: j.fitzpatrick@ucc.ie 


\section{INTRODUCTION}

For milk chocolate production, milk solids may be added in the form of milk powder or as chocolate crumb. The two main types of whole milk powder available to the chocolate producer are roller-dried and spray-dried powder. Roller-dried powder is preferred as it gives optimum chocolate viscosity, while spray-dried powder yields chocolate with a much higher viscosity [22]. This is due to differences in physical properties. Roller-dried powder has a high free-fat content of up to $90 \mathrm{~g} \cdot 100 \mathrm{~g}^{-1}$ fat while spray-dried powder has a low free-fat content of less than $10 \%$. Roller-dried powder tends to have larger mean particle size of around $150 \mu \mathrm{m}$ and low vacuole volume, while spray-dried powder has smaller particle size of about $70 \mu \mathrm{m}$ and a high vacuole volume. Consequently, work has been conducted to evaluate how to produce spraydried milk powders with properties close to roller-dried powders $[6,8]$ and to investigate how the properties of these novel powders affect the quality of chocolate [7,9]. The ultimate goal is to produce spray-dried milk powders, which have similar functionality to roller-dried powders in the production of chocolate. Powder with high free-fat content is required and larger particle size is desirable. High free-fat content may be achieved by increasing the protein to lactose ratio using ultrafiltration. Alternatively, higher fat milk powder (e.g. $55 \mathrm{~g}$ fat $\cdot 100 \mathrm{~g}^{-1}$ powder) has much higher free-fat content than whole milk powder, thus a blend of high fat powder and skim milk powder may be used to produce a $26 \%$ fat powder with much higher free-fat than whole milk powder. Varying the particle size of the powder particles in tall-form dryers can be achieved using different nozzle atomisers.

There is a large quantity and variety of dairy ingredients produced industrially in powder form, and there is a need for information about their handling and processing characteristics, in particular their powder flow properties. Flow problems in hoppers and silos are commonplace problems for engineers and process operatives [13]. These problems may manifest themselves as unreliable inconsistent flow that reduces pro- duction rate and may give rise to excessive spillage and dust generation. These problems are usually associated with the flow pattern inside the silo. The worst-case scenario is no flow. This can occur when the powder forms a cohesive arch across the opening, which has sufficient strength within the arch to be self-supporting. Mass flow is the ideal flow pattern where all the powder is in motion and moving downwards towards the opening. Funnel flow is where powder does not slip along the wall surface and instead starts moving out through a central "funnel" that forms within the powder, after which the powder against the wall collapses into and moves through the funnel. This process continues until the silo empties or until another no flow scenario occurs with the development of a stable rathole. Most flow problems are caused by a funnel flow pattern and can be cured by altering the pattern to mass flow $[5,12,15]$.

Measurement of powder flow properties is necessary for the design of mass flow hoppers. Jenike [4] pioneered the application of shear cell techniques for measuring powder flow properties. In conjunction with the measured property data, he applied twodimensional stress analysis in developing a mathematical methodology for determining the minimum hopper angle and hopper opening size for mass flow from conical and wedge shaped hoppers. A hopper is the lower converging section of a silo and the hopper angle is the angle between the converging section and the horizontal. The measured flow properties used in this methodology are the flowfunction, the effective angle of internal friction and the angle of wall friction. The flowfunction is a plot of the unconfined yield stress (UYS) of the powder versus major consolidating stress (MCS), and represents the strength developed within a powder when consolidated, which must be overcome to make the powder flow (Fig. 1). A cohesive arch will form preventing discharge if this strength is not overcome by the gravity force acting due to the powder above. A flowfunction lying towards the bottom of the graph represents easy flow, and more difficult flow is represented as the flowfunctions move upwards in an anticlockwise direction. The flow index is 
Table I. Jenike's classification of powder flowability (extended by Tomas [21]).

\begin{tabular}{lccccc}
\hline Flowability & hardened & $\begin{array}{c}\text { very } \\
\text { cohesive }\end{array}$ & cohesive & $\begin{array}{c}\text { easy } \\
\text { flowing }\end{array}$ & $\begin{array}{c}\text { free } \\
\text { flowing }\end{array}$ \\
\hline Flow index & $<1$ & $<2$ & $<4$ & $<10$ & $>10$ \\
\hline
\end{tabular}

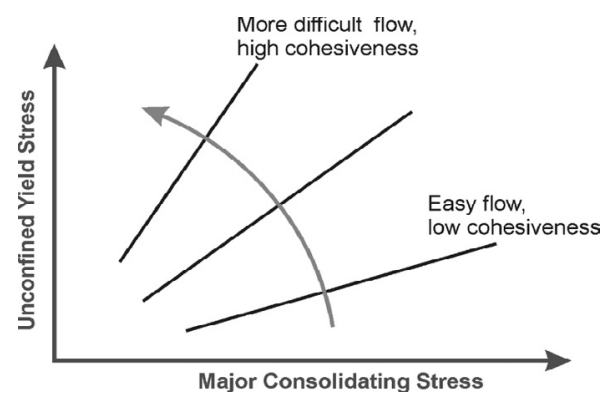

Figure 1. Flowfunctions: easy vs. difficult flow.

defined as the inverse slope of the flowfunction. Jenike used the flow index to classify powder flowability with higher values representing easier flow. This was extended by Tomas [21] and is presented in Table I.

Wall friction is a critical parameter in the design and operation of hoppers and silos for storage and discharge of bulk solids [14]. It is the frictional resistance to powder flow that exits between the powder and hopper/silo wall material. This is often measured using a Jenike shear tester, whereby the powder is packed into a ring, which is placed upon a coupon of hopper wall material. The shear stress required to overcome the frictional resistance of the powder to move along the coupon is measured for a number of normal stresses. From this, a wall yield locus (WYL) is constructed by plotting failure shear stress versus normal stress, as illustrated in Figure 2. The wall friction coefficient is obtained by evaluating the slope of a straight-line from the origin intersecting the WYL at the required normal stress. The angle of wall friction is the angle between this line and the horizontal. For most powders, the WYL intersects the shear stress axis above the origin, and as a result, the wall friction co-efficient and angle of

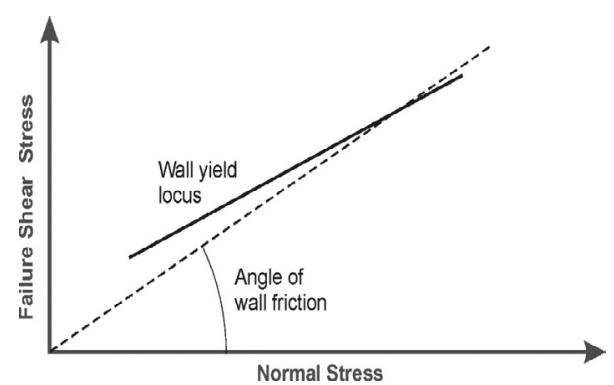

Figure 2. Angle of wall friction.

wall friction will decrease with increasing normal stress. Wall friction is the dominant parameter in determining the minimum hopper angle required to ensure mass flow, which is the desirable flow pattern for consistent reliable flow. If the hopper angle is less than this minimum, then it is likely that the powder will not slip down along the hopper wall surface and a funnel flow pattern will exist. This is undesirable, because there are many flow problems caused by funnel flow, including ratholing, erratic flow, flooding and segregation. Consequently, measurement of the wall friction characteristic of a representative powder sample under representative storage conditions is required in the design of mass flow hoppers to achieve consistent reliable discharge.

Many milk powders are cohesive and many industrial silos storing them have mechanical and pneumatic discharge aids to help prevent arching and ratholing in an effort to maintain consistent reliable flow. It was anticipated that producing powders with much higher free-fat content may lead to greater flow problems. Consequently, the focus of this work was to investigate the influence of powder properties and storage conditions on the flowability of spray-dried 
milk powders with particular reference to powder properties affecting the suitability of these novel powders for chocolate manufacture. These properties include fat and free-fat content, particle size and the blending of high fat powder with skim milk powder.

\section{MATERIALS AND METHODS}

\subsection{Milk powders}

Commercial skim milk powder (SMP) and whole milk powder (WMP) were donated by Dairygold in Mallow, Ireland, and a high fat powder (HFP) with $73 \%$ milk fat content was donated by Kerry Ltd. in Listowel, Ireland.

Teagasc Dairy Products Research Centre in Fermoy, Ireland, supplied a number of powders produced in their pilot-scale spray driers. These were:

(i) seven $26 \%$ fat milk powders with free-fat contents ranging from $12.7 \%$ to $74.2 \%$;

(ii) seven $26 \%$ fat milk powders with particle sizes ranging from 59 to $239 \mu \mathrm{m}$.

They also supplied five roller-dried whole milk powders.

\subsection{Physical properties}

Particle size distribution was measured by laser diffraction using the Malvern Mastersizer MSS with powder feeder unit. Moisture content (wet basis) was measured by weighing $3 \mathrm{~g}$ of a sample before and after drying in an oven at $105^{\circ} \mathrm{C}$ for 3 days. Each test was carried out in triplicate.

\subsection{Flowfunction measurement}

An annular shear cell was used for measuring the flowfunction and effective angle of internal friction and is the same as that described by Teunou et al. [20]. It has a fixed shearing rate of $7 \mathrm{~mm} \cdot \mathrm{min}^{-1}$ and external and internal diameters of $164 \mathrm{~mm}$ and $120 \mathrm{~mm}$, respectively. The milk powder was removed from its package and packed into the annular shear cell. The annular shear cell was then placed in a chamber, at a tem- perature of $20^{\circ} \mathrm{C}$, where the shear tests for measuring the instantaneous flow function were conducted. The procedure used to measure the instantaneous flow function is that recommended by the Standard Shear Test Technique (SSTT), using the Jenike shear cell [3].

To study the influence of temperature and relative humidity, the annular shear cell was enclosed in an insulated cabinet [18]. The desired temperature was controlled using a Haake F3 heating/cooling system. Relative humidity was controlled by placing a tray of a saturated salt solution in the base of the sealed cabinet. There was a fan in the cabinet to maintain a uniform atmosphere, and the values of temperature and relative humidity in the cabinet were recorded by a thermometer and a hygrometer located inside the cabinet. For the relative humidity studies, the cell was packed and the free surface was exposed to the relative humidity for $18 \mathrm{~h}$ prior to placing the lid on top and starting the test. At the end of the test, samples were taken from the shearing region for moisture content measurement.

\subsection{Angle of wall friction}

The wall yield locus of a powder was measured using a Jenike shear cell $(95 \mathrm{~mm}$ internal diameter) whereby the cylindrical base of the cell was replaced by a flat plate of stainless steel 304 commonly used in food processing. The wall yield locus was obtained by measuring the horizontal stress required to make the powder fail at the following normal stresses: 5.9, 4.4, 3.7, 3.0, 2.3 and $1.6 \mathrm{kPa}$. The procedure used is that recommended by the Standard Shear Test Technique (SSTT), using the Jenike shear cell. The angle of wall friction $\left(\phi_{\mathrm{W}}\right)$ reported is the angle formed with the horizontal by a line drawn from the origin to a point on the wall yield locus with a normal stress of either $4.4 \mathrm{kPa}$ or $5.9 \mathrm{kPa}$.

\section{RESULTS AND DISCUSSION}

\subsection{Effect of fat content}

The measured flowability, as classified by flow index (Tab. I) of SMP, WMP and 
Table II. Physical and flow properties of commercial milk powders at ambient conditions $\left(20^{\circ} \mathrm{C}\right)$.

\begin{tabular}{lcccccccc}
\hline \multicolumn{9}{c}{ Physical properties } \\
\hline Powder & $\begin{array}{c}\text { Fat } \\
\text { content } \\
(\% \mathrm{w} / \mathrm{w})\end{array}$ & $\begin{array}{c}\text { Mean } \\
\text { particle size } \\
(\mu \mathrm{m})\end{array}$ & $\begin{array}{c}\text { Moisture } \\
\text { content } \\
(\% \mathrm{w} / \mathrm{w})\end{array}$ & $\begin{array}{c}\text { Bulk } \\
\text { density } \\
\left(\mathrm{kg} \cdot \mathrm{m}^{-3}\right)\end{array}$ & $\begin{array}{c}\text { Particle } \\
\text { density } \\
\left(\mathrm{kg} \cdot \mathrm{m}^{-3}\right)\end{array}$ & $\begin{array}{c}\text { Flow } \\
\text { index }\end{array}$ & $\begin{array}{c}\delta_{\mathrm{E}} \\
\left({ }^{\circ}\right)\end{array}$ & $\begin{array}{c}\phi_{\mathrm{w}} \\
\left({ }^{\circ}\right)\end{array}$ \\
\hline SMP & 0.9 & 53 & 4.7 & 646 & 1133 & 6.1 & 51.5 & 15.4 \\
WMP & 26 & 99 & 3.3 & 627 & 1180 & 1.45 & 48 & 11 \\
HFP & 73 & 76 & 2 & 433 & 934 & 1.78 & 50 & 12 \\
\hline
\end{tabular}

the $73 \%$ high fat powder (HFP) is presented in Table II. The cohesion developed within the SMP is much less than that of WMP, and this is in agreement with work presented by Rennie et al. [16]. The WMP and HFP have similar flowability and are considered as very cohesive powders by their flow index. On the other hand, SMP is classified as an easy flow powder. As a result, WMP and HFP are much more susceptible to cohesive arching than SMP.

Surface composition of the powder particles is expected to play an important role in its flow behaviour because flowability involves overcoming the surface attractions between powder particles. Recent work by Kim et al. [10] applied electron spectroscopy for chemical analysis to measure the surface composition of 4 industrial spraydried milk powders, including SMP (1\% fat), WMP (26.5\% fat) and a cream powder ( $71.5 \%$ fat). They showed that the surface fat content of these powders was much higher than their bulk average compositions, with the surface fat contents of SMP, WMP and cream powder being $18 \%, 98 \%$ and $99 \%$, respectively. The surface fat content of SMP is a lot less than both the WMP and cream powder and this may explain its lower cohesiveness. The surfaces of both the WMP and the cream powder are nearly totally covered with fat, and this may explain the similarity of the flowfunctions of WMP and HFP measured in this work.

Hopper wall friction characteristic is very important as this has a major role in determining if mass or funnel flow will occur during discharge from a silo. The angles of wall friction (at $5.9 \mathrm{kPa}$ normal pressure) are presented in Table II. The wall
Table III. Physical properties and flowability of $26 \%$ fat powders with varying free-fat content.

\begin{tabular}{lcccc}
\hline Powder & $\begin{array}{c}\text { Free-fat } \\
\text { content } \\
(\% \mathrm{w} / \mathrm{w})\end{array}$ & $\begin{array}{c}\text { Mean } \\
\text { particle } \\
\text { size } \\
(\mu \mathrm{m})\end{array}$ & $\begin{array}{c}\text { Moisture } \\
\text { content } \\
(\% \mathrm{w} / \mathrm{w})\end{array}$ & $\begin{array}{c}\text { Flow } \\
\text { index }\end{array}$ \\
\hline 1 & 12.6 & 83 & 4.5 & 2.65 \\
2 & 13.2 & 58 & 3.7 & 2.36 \\
3 & 30.6 & 47 & 3 & 2.0 \\
4 & 47.9 & 56 & 3 & 2.15 \\
5 & 49.3 & 55 & 3 & 1.88 \\
6 & 58.8 & 69 & 3.9 & 2.0 \\
7 & 74.2 & 68 & 3.8 & 2.13 \\
\hline
\end{tabular}

friction values obtained for the stainless steel wall material tested are considered low to medium. Even though the SMP is considered an easier flow powder than either WMP or HFP based on flow index, it adheres more strongly to the stainless steel wall material tested. As a result, a steeper hopper angle is required to obtain mass flow for the SMP than either of the other two powders.

\subsection{Effect of free-fat content}

The physical properties of seven $26 \%$ fat powders with free-fat content varying from $12.6 \%$ to $74.2 \%$ are presented in Table III. These are similar in terms of particle size, and moisture content except for the first powder which has both higher particle size and moisture content. The flowability of the powders, as classified by flow index, is also presented in Table III, and these are also similar. There was no relationship between free-fat content and powder cohesion for 
Table IV. Effect of particle size on the flow properties of milk powders with $26 \%$ milk fat content.

\begin{tabular}{lcccc}
\hline $\begin{array}{l}\text { Mean } \\
\text { particle size } \\
(\mu \mathrm{m})\end{array}$ & $\begin{array}{c}\text { Moisture } \\
\text { content } \\
(\% \mathrm{w} / \mathrm{w})\end{array}$ & $\begin{array}{c}\text { Flow } \\
\text { index }\end{array}$ & $\begin{array}{c}\delta_{\mathrm{E}} \\
\left(^{\circ}\right)\end{array}$ & $\begin{array}{c}\phi_{\mathrm{W}} \\
\left({ }^{\circ}\right)\end{array}$ \\
\hline 59 & 4.8 & 1.9 & 49 & 7.3 \\
69 & 5.3 & 1.7 & 51 & 11.4 \\
150 & & 2.5 & & 7.5 \\
191 & 6.7 & 3.4 & 60 & 7.1 \\
212 & 6.4 & 3.3 & 57 & 7.8 \\
220 & 5.3 & 5 & 57 & 8 \\
239 & 5.3 & 10.9 & 49 & 6.4 \\
\hline
\end{tabular}

these powders, although the $12.7 \%$ free-fat powder had the lowest free-fat content and was the least cohesive. All in all, the measurements showed that free-fat content in the range of 13 to $74 \%$ had no major influence on the cohesiveness of $26 \%$ fat powder at $20{ }^{\circ} \mathrm{C}$. Buma [1] also found no correlation between free-fat content and the cohesion of WMP with similar mean particle size.

The free-fat content measured will depend on the solvent extraction process, including extraction time and temperature. In addition to the surface free-fat, solvent extraction will extract free-fat from within the bulk of the powder particles. As powder flowability depends on surface composition, it is the surface free-fat content that is likely to play a key role in determining powder flowability and stickiness. Kim et al. [10] found that the outer surface of industrial spray-dried WMP is largely covered by free (unprotected) fat and that fat globules protected by protein are located underneath this surface free-fat. As industrial spraydried WMP has low free-fat content and its surface is nearly totally covered by free-fat, then increasing the powder free-fat content will not contribute to additional surface coverage with free-fat. This may explain why increase in free-fat content had no significant effect on the flowfunctions of the WMP powders measured in this work.

\subsection{Effect of particle size}

Milk powders, with $26 \%$ milk fat content, and different mean particle sizes were

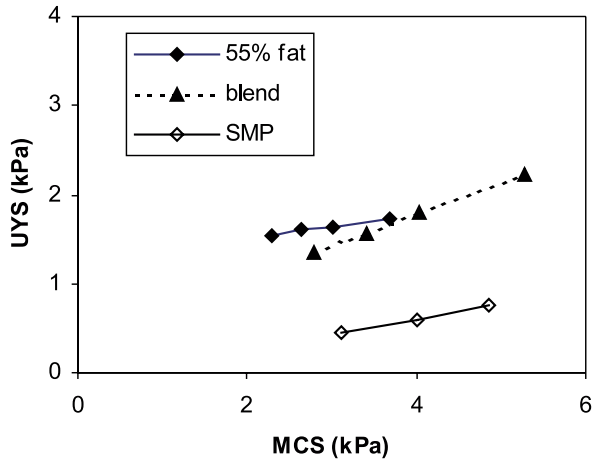

Figure 3. Effect on the flowfunction of blending a 55\% fat milk powder with SMP to produce a blend with $26 \%$ fat content.

produced using different size pressure nozzles on a pilot scale tall form drier. The flow properties of each of these powders were measured. Table IV illustrates the effect of particle size on the flowability of the milk powders as classified by flow index. Reducing particle size from 239 to $59 \mu \mathrm{m}$ had a significant effect on powder cohesion by reducing the flow index from over 10 (freeflowing) to just below 2 (very cohesive). This is an expected result as reducing particle size increases the contact area between particles allowing greater interaction between cohesive forces.

The measured angles of wall friction for each of the powders were lower than expected when compared to those for the commercial powders above. Particle size had no significant effect on the wall friction of any of the powders, as presented in Table IV, and the effective angle of internal friction tended to increase with particle size.

\subsection{Blending of a $55 \%$ fat powder with SMP}

A high fat milk powder containing 55\% fat with high free-fat content was blended with SMP to produce a blend with a fat content of $26 \%$ fat. The flowfunction of the blend was located between the $55 \%$ fat powder and SMP, as illustrated in Figure 3, and was classified as being cohesive. Likewise, the wall friction of the blend was in 


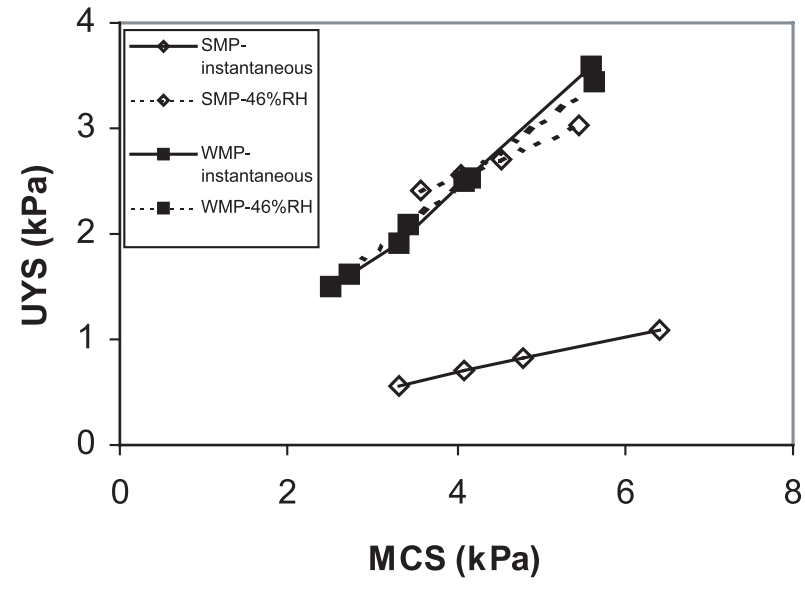

Figure 4. Effect of exposure to moisture in air at $46 \%$ relative humidity (RH) and $20^{\circ} \mathrm{C}$ on the flowfunctions of SMP and WMP.

Table V. Effect of exposure to moisture in air at $46 \%$ relative humidity (RH) and $20{ }^{\circ} \mathrm{C}$ for $18 \mathrm{~h}$ on the flowability of SMP, WMP and HFP.

\begin{tabular}{lcccc}
\hline Powder & $\begin{array}{c}\text { Moisture } \\
\text { content }(\% \mathrm{w} / \mathrm{w})\end{array}$ & $\begin{array}{c}\text { Flow } \\
\text { index }\end{array}$ & $\begin{array}{c}\delta_{\mathrm{E}} \\
\left(^{\circ}\right)\end{array}$ & $\begin{array}{c}\phi_{\mathrm{W}} \\
\left(^{\circ}\right)\end{array}$ \\
\hline $\begin{array}{l}\text { SMP } \\
\quad \text { Instantaneous }\end{array}$ & 4.7 & 6.1 & 51.5 & 15.4 \\
$\quad 46 \%$ RH & 7.5 & 3 & 56 & 16.5 \\
WMP & & & & 11 \\
$\quad$ Instantaneous & 3.3 & 1.45 & 48 & 13.4 \\
$\quad 46 \%$ RH & 6.9 & 1.6 & 52 & \\
\hline
\end{tabular}

between the higher value of SMP and the lower value of the $55 \%$ fat powder.

\subsection{Effect of moisture content and amorphous lactose content}

SMP and WMP were exposed to moisture in air at $46 \%$ relative humidity $\left(20^{\circ} \mathrm{C}\right)$ over an 18-hour period. Both powders picked up moisture from the air, as shown in Table V. The effect of this moisture increase on the flowfunctions of the powders is illustrated in Figure 4 and the corresponding flow index is presented in Table $\mathrm{V}$. The cohesiveness of WMP was not significantly affected; however, there was a large increase in the cohesiveness of SMP. Many food powders containing lactose in its amorphous state may crystallize producing solid crystal bridges between the particles.
Crystallization will only take place if the powder temperature is greater than its glass transition temperature $\left(\mathrm{T}_{\mathrm{g}}\right)$, whereby the molecules have sufficient mobility to initiate crystallization [17]. $T_{g}$ is usually well above the storage temperature for most dry powders. However, lactose in its amorphous state is very hygroscopic and will readily sorb moisture from ambient air, and this increase in moisture will cause a significant reduction in $\mathrm{T}_{\mathrm{g}}$. Crystallization will initiate if $T_{g}$ is reduced below the powder temperature, resulting in solid bridges between powder particles, which can greatly increase the cohesiveness of the powder. As SMP has the highest lactose content and the highest moisture after the 18-hour exposure, this mechanism may explain the increase in cohesion. Moisture sorption had only a small effect on the wall friction of each powder 
with small increases at higher moistures, as shown in Table V. Effective angles of internal friction also increased a little at higher moistures.

\subsection{Effect of storage conditions}

Storage and handling conditions may have a significant influence on the flowability of dairy powders. Fitzpatrick et al. [2] showed that increased temperature in the range of 10 to $30^{\circ} \mathrm{C}$, where most fat melting occurs, can increase powder cohesiveness in powders with significant fat content due to the formation of liquid fat bridges between particles. Furthermore, there is a sharp increase in the cohesiveness and adhesion of powders to surfaces when the temperature is elevated above the "sticky" temperature [11]. Cooling of milk powder may produce lumping and caking. Cooling of powder with significant fat content from a temperature where liquid fat bridges exist down to below $10^{\circ} \mathrm{C}$ may lead to solidification of these bridges resulting in lump and cake formation.

The effect of sorbing moisture from air has already been highlighted, however intimate contact between the air and powder particles is required as moisture diffuses very slowly through a packed bed of powder. Storage time may influence powder flowability. Teunou et al. [19] showed that a packed bed of powder may become more cohesive over time due to bed compaction leading to greater contact between powder particles allowing attractive forces to interact more strongly. Furthermore, as discussed already, powder may sorb moisture over time leading to poorer flowability. Lactose crystallization requires time, thus crystal bridges between particles may build up over time eventually leading to lump formation and caking after a certain storage time.

\subsection{Cohesiveness of roller-dried whole milk powder}

The free fat content of the five rollerdried whole milk powders ranged from 66 to $71 \%$, the mean particle size ranged from 138 to $155 \mu \mathrm{m}$ and the moisture content ranged from 2.6 to $3.5 \%$. The flowfunction for each of these powders was measured. Two flowfunctions representing the easiest

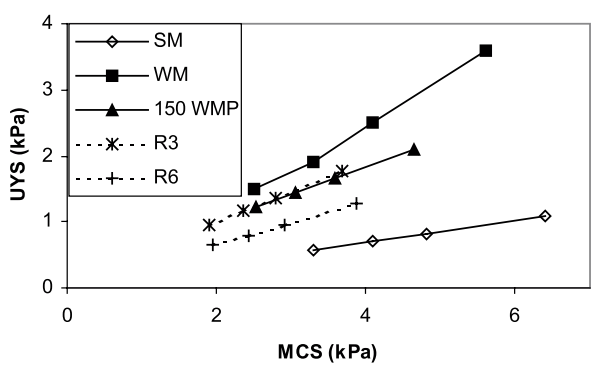

Figure 5. Comparison of the flowfunctions of two roller-dried whole-milk powders (R3 and R6), a spray-dried WMP and SMP, and a spraydried WMP with mean particle size of $150 \mu \mathrm{m}$ (150 WMP).

flow and most difficult flow roller-dried powders are presented in Figure 5 (the other three lie between these extremes), along with the flowfunctions of the commercial spray-dried SMP and WMP. The flowfunction of the WMP powder with a particle size of $150 \mu \mathrm{m}$, similar to the roller-dried powders, is also included. The flowfunctions of the roller-dried whole-milk powders are in between the spray-dried WMP and SMP. The larger particle size is most likely the reason why the roller-dried WMP is less cohesive than the spray-dried WMP. The $150 \mu \mathrm{m}$ spray-dried WMP has similar cohesiveness to the roller-dried powders having similar particle size. Consequently, the much higher free-fat content of the roller-dried powders did not result in greater cohesiveness.

\section{CONCLUSION}

Shear testing techniques were applied to measure the effect of a number of spraydried milk powders properties, important in chocolate manufacture, on milk powder flow properties. Increasing fat content from $1 \%$ fat (SMP) to $26 \%$ fat (WMP) had a major effect on increasing the cohesiveness of the powder; however, increasing the fat content to $73 \%$ fat (HFP) showed no increase in cohesiveness. This is most likely due to large difference in surface fat between SMP and WMP and the very small difference between WMP and HFP. On the other hand, SMP displayed significantly greater wall friction on a type 304 stainless steel than WMP. Greater cohesiveness leads to more 
difficult handling powders that are more prone to cohesive arching. Greater wall friction can make discharge from hoppers and silos more prone to funnel flow discharge and the problems associated with funnel flow.

The free-fat content of the $26 \%$ fat powders tested had no effect on powder cohesiveness. Varying powder particle size from $59 \mu \mathrm{m}$ to $239 \mu \mathrm{m}$, by using different atomisation nozzles, changed a $26 \%$ fat powder from being a very cohesive powder to a free flowing powder. This variation in particle size had no significant effect on wall friction. Blending of $55 \%$ fat powder with SMP to produce a blend with $26 \%$ fat produced a powder with cohesiveness and wall friction characteristics in between the parent powers.

Amorphous lactose content will increase the cohesiveness and caking characteristics of milk powder if the storage temperature is greater than the glass transition temperature, which strongly depends on the moisture content of the powder and exposure of powder to moisture in air. SMP is more susceptible than WMP or HFP because of its greater lactose and amorphous lactose content, and because non-lactose components will hinder the mobility of the amorphous lactose molecules from crystallizing and forming solid bridges between powder particles.

Acknowledgements: The project was funded by the Irish Government under the National Development Plan 2000-2006.

\section{REFERENCES}

[1] Buma T.J., Free fat in spray-dried whole milk 5. Cohesion. Determination, influence of particle size, moisture content and free-fat content, Neth. Milk Dairy J. 25 (1971) 107-122.

[2] Fitzpatrick J.J., Iqbal T., Delaney C., Twomey T. Keogh M.K., Effect of powder properties and storage conditions on the flowability of milk powders with different fat contents, J. Food Eng. 64 (2004) 435-444.

[3] Institution of Chemical Engineers, Standard shear testing technique for particulate solids using the Jenike shear cell, UK, 1989.

[4] Jenike A.W., Storage and flow of solids, Bulletin 123, Engineering Experiment Station, University of Utah, USA, 1964.

[5] Johanson J.R., Troubleshooting bins, hoppers and feeders, Chem. Eng. Prog. 98 (2002) 24-36.
[6] Keogh K., Twomey M., O’Kennedy B., Mulvihill D., Effect of milk composition on spray-dried high-fat milk powders and their use in chocolate, Lait 82 (2002) 531-539.

[7] Keogh M.K., Murray C.A., O’Kennedy B.T., Effects of selected properties of ultrafiltered spray-dried milk powders on some properties of chocolate, Int. Dairy J. 13 (2003) 719-726.

[8] Keogh M.K., Murray C.A., O’Kennedy B.T., Effects of ultrafiltration of whole milk on some properties of spray-dried milk powders, Int. Dairy J. 13 (2003) 995-1002.

[9] Keogh K., Murray C., Kelly J., O’Kennedy B., Effect of the particle size of spray-dried milk powder on some properties of chocolate, Lait 84 (2004) 375-384.

[10] Kim E.H.J., Chen X.D., Pearce D., Surface characterization of four industrial spray-dried powders in relation to chemical composition, structure and wetting property, Colloids Surf. B: Biointerfaces 26 (2002) 197-212.

[11] Kudra T., Sticky region in drying - definition and identification. Internet publication, available at:

http://cetc-varennes.nrcan.gc.ca/fichier.php/ 7477/2002-057e.pdf (2002).

[12] Marinelli J., Carson J.W., Solve solids flow problems in bins, hoppers, and feeders, Chem. Eng. Prog. 88 (1992) 22-28.

[13] McGee E., Go with the flow, Chem. Eng. 755 (2004) 40-41.

[14] Prescott J.K., Ploof D.A., Carson J.W., Developing a better understanding of wall friction, Powder Process. Handl. 11 (1999) 25-36.

[15] Purutyan H., Pittenger B.H., Carson J.W., Solve solids handling problems by retrofitting, Chem. Eng. Prog. 94 (1998) 27-39.

[16] Rennie P.R., Chen X.D., Hargreaves C., Mackereth A.R., A study of the cohesion of dairy powders, J. Food Eng. 39 (1999) 277-284.

[17] Roos Y.H., Importance of glass transition and water activity to spray drying and stability of dairy powders, Lait 82 (2002) 475-484.

[18] Teunou E., Fitzpatrick J.J., Effect of relative humidity and temperature on food powder flowability, J. Food Eng. 42 (1999) 109-116.

[19] Teunou E., Fitzpatrick J.J., Effect of storage time and consolidation on food powder flowability, J. Food Eng. 43 (2000) 97-101.

[20] Teunou E., Fitzpatrick J.J., Synnott E.C., Characterisation of food powder flowability, J. Food Eng. 39 (1999) 31-37.

[21] Tomas J., Schubert H., Particle characterisation, in: Partec 79, Nurnberg, Germany, 1979, pp. 301-319.

[22] Twomey M., Keogh K., Milk powder in chocolate, in: Farm \& Food - Teagasc Research and Development Digest, Spring 1998, pp. 9-11. 